Jurnal Keperawatan Padjadjaran /Padjadjaran Nursing Journal

ISSN 2338-5324 (print)

ISSN 2442-7276 (online)

Online di http://jkp.fkep.unpad.ac.id

DOI : $10.24198 / \mathrm{jkp}$

\title{
Development of Team Cohesiveness Measurement Instruments in Interprofessional Collaborative Practice in Health Care
}

\author{
F. Sri Susilaningsih, Henny Suzana Mediani, Titis Kurniawan \\ Faculty of Nursing Universitas Padjadjaran \\ Email:f.sri@unpad.ac.id
}

Submitted: 6-12-2017 Accepted: 30-4-2018Ｐublished: 30-4-2018

\begin{abstract}
Health care management has an obligation to always provide safe, sustainable, comprehensive, quality and satisfactory health care for both the service user and care provider. The management and culture are built through the Interprofessional Health Care Collaborative Practice Model (MPIPK), which are implemented through four model components, i.e. the clinical pathway of patient management, team management of patients, patient care integrated documentation, and interdisciplinary patient problem solving through interdisciplinary case conference forums. In order to realize interprofessional collaboration practices, a cohesive climate is required that supports group functions and performances, and an instrument is needed to measure the team cohesiveness of this model. This research was conducted to developateam cohesivenessmeasurementinstrumentin theinterprofessional collaborationofhealthcare. The instrumentation research design was carried out through the following steps: 1) Preparations of the instrument design commenced from the synthesis theory related to collective culture and individual culture on four components of the model; 2) Validation of the contents of the instrument with related experts; 3) Construct validation with 237 healthcare practitioners in an accredited hospital setting. Expertjudgmentresults on instrumentrelevance(CVI)ranged from 0.77 to 0.91 , the essence of instrument contents (CVR) was in range $(+) 0.27-0.63, \mathrm{CVI}$ and CVR scores indicated the relevant and essential content of the instrument. Test results of all constructed items were valid $(0.283-0.847)$ and reliable, $\alpha$ Cronbach on 4 components $(0.792-0.963)$ so, it is feasible to be used to measure the team cohesiveness.
\end{abstract}

Keywords: Collective culture, individual culture, instrument, interprofessional collaboration. 
F. Sri Susilaningsih : Development of Team Cohesiveness Measurement Instruments

\section{Introduction}

Patient problems in the scope of health care services including hospital management cannot be handled completely by one scientific discipline and profession only. Various professions of different scientific disciplines contribute to solving patients' problems, sharing roles and responsibilities through interprofessional collaborations.

An interdisciplinary/interprofessional collaboration is a process of cooperation and problem-focused role sharing (Petri, 2010), the elements necessary for a successful interdisciplinary collaboration are awareness of roles, interpersonal relationship skills, and supported genuine endeavors. Combining various disciplines, personalities, and a range of skills in one process can lead health professionals to explore and discover potential problems and areas that need improvement and create a work environment based on mutual trust, appreciation and mutual desire to do the best for the patient (Huber, 2010). Interdisciplinary collaborations will be developed and realized when the professionals involved in handling the same problem grow and learn in a mutually supportive situation, mutual trust, mutual respect for the professional role, and the willingness and ability to share roles in decision-making, and interventions. In brief, the interdisciplinary collaborative practice can be realized if practitioners have an attitude that promotes a collective culture namely the tendency to behave collectively characterized by more share expertise than the tendency to promoting the individual culture who prioritized personal autonomy. Both the collective and individual cultures are needed in teamwork, but cohesive teams are indispensable in the collaborative practice. A cohesive team is a team in which the partnership pattern is supported by the practitioner's attitude to promote the collective culture rather than the individual culture.

The partnership pattern in the patient managementand problems has been developed by Susilaningsih (2011) through an Integrated Inpatient Service Model, hereinafter referred to as the Interprofessional Health Care Collaborative Model. This collaborative model is constructed due to the patient care in the hospital should be carried out with priority to the patient safety, fully implemented, sustainable and qualified. The involvement of many health workers with different scientific backgrounds, different profession cultures, and existence of power imbalances can lead to fragmented, overlapping and potential prone services to patient safety issues. WHO (2009) reveals that $70-80 \%$ of errors in health care are caused by poor communication and understanding within teams; good teamwork may help reduce patient safety problems.

Teamwork will be cohesive if professionals prioritize share expertise mechanisms rather than personal autonomy. Share expertise is an important characteristic of collective behavior while personal autonomy becomes an important feature of individual behavior. To assess the cohesiveness of the teamwork, an instrument is needed to measure collective behavior and individual behavior in the interprofessional collaborative process on the 4 components of the Interprofessional Health Care Collaborative Model in the inpatient setting of the hospital, namely the integrated patient management pathway through an integrated clinical pathway, interdisciplinary team management of patients, integrated documentation and joint problem-solving through interdisciplinary case conference.

The existence of valid instruments for measuring team cohesiveness in interprofessional collaborations is essential. The reference search for the existence of instrument to evaluate interprofessional collaboration (Reeves et al., 2010) has obtained 11 types of instruments which included: the Interaction Process Analysis (Bales, 1976) which creates categories and understanding of interactions within groups; the System for multiple levels of observation of Groups (Bales \& Cohen, 1979) which measures the individual behavior based on three dimensions: prominence, sociability and task orientation; the Team Effectiveness Questioner (Poulton \& West, 1993; 1994) which measures team effectiveness in 4 dimensions: teamwork, organizational efficiency, health care practices, and patient-centered care; the Team Climate Inventory (Anderson \& West, 1994; 1998) is developed to measure team objectives, 
F. Sri Susilaningsih : Development of Team Cohesiveness Measurement Instruments

team participation, quality and support for innovation; the Multidisciplinary Collaboration (Carroll, 1999) measures the perception of collaboration based on 18 vignettes. The focus of measurement is a general collaboration, patient care process, communication, and teamwork; the Collaborative Practice Questioner (Way et al., 2001) measures the perception of collaborative practice between the health profession and social workers, its focus is on communication, decision-making, coordination, and collaboration; the Index of Interdisciplinary Collaboration (Bronstein, 2002)measures the perception of collaboration with a focus on interdependence, professional activity, ownership of common goals and reflection on processes; the Role Perception Questionnaire (Mac Kay, 2004) measures the perceptions of health professionals and social workers on their respective roles and roles of collaborative partners; The Team Survey (Delva \& Jamieson, 2005) measures four factors: team identification and communication, metacognition of team goals and performance, team potential and team roles; the Aston Team Performance inventory (2010) measures factors affecting the team effectiveness consisting of team and leadership processes and the team's overall performance; the Interprofessional Collaboration Scale (Kenaszchuk et al., 2010) measures the perception of collaboration between physicians, nurses and other health professions.

Of the 11 instruments relating to the interprofessional collaborative practice outlined above, none has measured the cohesiveness of teams in the context of implementing interprofessional collaborative models that have four components, namely the integrated patient management pathway through integrated clinical pathways, interdisciplinary team management of patients, patient care integrated documentation, and joint problem-solving through interprofessional discussions. Thus, it is important to develop a team cohesiveness tool in the practice of integrated health care services.

\section{Method}

The preparation of team cohesiveness instruments in the interprofessional collaboration of health services was conducted as follows: 1) The synthesis of the theory related to the context variable to be measured. The team cohesiveness was determined by the tendency toward behavior that led to the individual and collective culture of the practitioners. The individual culture is more dominated by personal and professional autonomy, while share expertise is an important feature of collective culture (Cohen, 2005); 2) Developing dimensions and indicator variables. The dimension whose team cohesiveness would be measured based on 4 components of the interprofessional collaborative model in health care (Susilaningsih, 2011) were the clinical pathway of patient management, team management of patients, patient care integrated documentation, and joint problem-solving through interprofessional discussions. The collaborative indicators referred to the four key ingredients needed to build interdisciplinary cooperation (Sullivan, 1999) were: the sense of control, information sharing, attention to overlap of responsibilities or areas of concern, and structuring interventions; 3 ) Developing grids and specifications related to the dimension and indicator of each variable. The instrumental grid was developed as follows: the instrument would measure the team cohesiveness in 4 components of the interprofessional health care collaborative model. Each component contained a statement comprising the four key points needed to build an interdisciplinary cooperation in relation to the components to be measured then; it determined which principal points in such interdisciplinary cooperation indicated the collective culture and individual culture; 4) Making notes of the instrument items. Writing down the instrument items referring to the process of numbers $1-3$; 5) The content validation was based on the expert judgment and construct validation. The content validation process was performed by requesting an expert's opinion on the content of the instument to establish 
F. Sri Susilaningsih : Development of Team Cohesiveness Measurement Instruments

the content validity index (CVI) regarding the relevance of the instrument items, and the content validity ratio (CVR) to determine if the instrument items were essential or not. The assessment was conducted by five experts consisting of a professor and hospital service management practitioner, a medical practitioner - a pediatrician $(\mathrm{K})$ with expertise in infections, a Master of Nursing and Nursing Practitioner in the Intensive Care Unit, a Nursing Doctor with expertise in the field of HIV/AIDS, and a Professor of Pharmacy. The CVI (content validity index) for each statement item was determined based on the expert judgment in the range of 1 (irrelevant) - 2 (somewhat relevant) 3 (relevant) - 4 (very relevant). CVI items were calculated on the basis of the number of experts assigning values 3 and 4 divided by the number of experts who gave the scores (Larsson, Tegern, Monnier, Skoglund, Helander, \& Persson et al., 2015). The CVI was expected to be 0.8 or more (Polit \& Beck, 2006). The CVI was required to revise items, replace or discard certain items.

As for the Content Validity Ratio (CVR), the expert was required to give a score for each item, 1 (not essential), 2 (important but not essential), and 3 (essential). CVR was calculated by counting the number of experts who scored " 3 " (essential) minus (N/2) divided by $(\mathrm{N} / 2)$ or by the following formula:

$$
\mathrm{CVR}=(\text { ne- } \mathrm{N} / 2) /(\mathrm{N} / 2)
$$

Where ne $=$ the number of experts who gave a score of $3, \mathrm{~N}$ is the number of experts. In this study, the number of experts was 5 . The range of values is from +1 to -1 . $\mathrm{A}+$ value indicates that at least half of the total number of experts judges the item to be

Table 1 Expert Rating toward Instrument Relevan

\begin{tabular}{clcccc}
\hline No & Model Component & $\begin{array}{c}\text { Number of } \\
\text { Item }\end{array}$ & $\begin{array}{c}\text { Range Index } \\
\text { per Item }\end{array}$ & CVI & Explanation \\
\hline 1 & $\begin{array}{l}\text { Clinical Pathways } \\
\text { of Patient } \\
\text { management }\end{array}$ & 18 & $0-1$ & 0.83 & $\begin{array}{l}\text { The number of items } \\
\text { with index below } 0.75:\end{array}$ \\
& & & & $\begin{array}{l}3 \text { items, revision of } \\
\text { language structure and } \\
\text { context }\end{array}$ \\
2 & $\begin{array}{l}\text { Team management of } \\
\text { patient }\end{array}$ & 18 & $0-1$ & 0.82 & $\begin{array}{l}\text { The number of items } \\
\text { with index below 0.75: } \\
\text { 3 items, revision of } \\
\text { language structure and } \\
\text { context }\end{array}$ \\
\hline
\end{tabular}

essential. The CVR Mean is an indicator of overall test content validity (Lawshe, 1975).

The test for the construct and reliability of the instrument was performed on 237 health care practitioners in KARS accredited hospitals, consisting of doctors and case managers (44), Nurses with minimum PK III (175), clinical pharmacy practitioners (7), nutritionists (11). The test for instrument validity and reliability were performed, the validity test used the Pearson Product Moment test while reliability used Alpha Cronbach.

In this study, the sample was 237 people. The $r$ table (n-2) at $n \geq 200$ was 0,195 , thus the instrument was valid if above 0,195 .

\section{Result}

The presentation of research results included the contents of the instrument on four components of the model, expert assessments of CVI, CVR, construct validity and reliability of the instrument.

Instrument contents: Based on the instrument grids, the components of the clinical pathway model and team management of patient, each consisted of 18 items with 9 items leading to a collective culture tendency and 9 items leading to an individual culture, whereas in the components of integrated documentation of patient care and joint problem-solving through interprofessional discussions, each consisted of 16 items with 8 items leading to the tendency of collective culture, and the other 8 items to the individual culture.

Relevance and essence of the instrument contents. Table 1 presented the relevance of the instrument contents (CVI) and Table 
F. Sri Susilaningsih : Development of Team Cohesiveness Measurement Instruments

\begin{tabular}{|c|c|c|c|c|c|}
\hline 3 & $\begin{array}{l}\text { Integrated } \\
\text { documentation of } \\
\text { patient care }\end{array}$ & 16 & $0-1$ & 0.91 & $\begin{array}{l}\text { The number of items } \\
\text { with index below } 0.75 \text { : } \\
2 \text { items, revision of } \\
\text { language structure }\end{array}$ \\
\hline 4 & $\begin{array}{l}\text { Joint problem- } \\
\text { solving through } \\
\text { interprofessional } \\
\text { discussions }\end{array}$ & 16 & $0-1$ & 0.77 & $\begin{array}{l}\text { The number of items with } \\
\text { index below } 0.75: 4 \text { items, } \\
\text { revision of language } \\
\text { structure }\end{array}$ \\
\hline
\end{tabular}

3 presented the essence of the instrument content (CVR) as follows:

The expert assessment for CVI on 4 components of the interprofessional health service collaboration model stated the highest index was on patient care integrated documentation while, the lowest was on the component of joint problem-solving through interprofessional discussions. Indexes of all four components of the model showed three of them were $>0.8$, one component was $<$ 0.8 but more than 0.75 . So, in general, the

Table 2 Revision of Instrument Item Contents based on Expert Judgment on the CVI Test

\begin{tabular}{|c|c|c|c|}
\hline Model Component & No of Item & Content of Statement/Item & Revision of Item \\
\hline \multirow[t]{3}{*}{$\begin{array}{l}\text { Clinical pathways } \\
\text { of patient } \\
\text { management }\end{array}$} & 11 & $\begin{array}{l}\text { I do/follow the visits together in an } \\
\text { interdisciplinary area (wing) where I work. } \\
\text { (Expert Comments/EC: more to collective } \\
\text { culture) }\end{array}$ & $\begin{array}{l}\text { I provide a cross- } \\
\text { disciplinary view of } \\
\text { expertise on visits }\end{array}$ \\
\hline & 13 & $\begin{array}{l}\text { I do not need to explain the action I take for } \\
\text { patients to my colleagues in the team. } \\
\text { (EC: necessary, explaining does not mean } \\
\text { reducing autonomy) }\end{array}$ & $\begin{array}{l}\text { I explain the actions I } \\
\text { take for patients to my } \\
\text { colleagues in teams when } \\
\text { necessary }\end{array}$ \\
\hline & 14 & $\begin{array}{l}\text { I do medical/nursing intervention } \\
\text { independently, without consulting my } \\
\text { colleagues. } \\
\text { (EC: Necessary, moreover, in a medical } \\
\text { intervention) }\end{array}$ & $\begin{array}{l}\text { I perform clinical } \\
\text { interventions according to } \\
\text { my competence and level } \\
\text { of clinical authority }\end{array}$ \\
\hline \multirow[t]{3}{*}{$\begin{array}{l}\text { Team management } \\
\text { of patient }\end{array}$} & 5 & $\begin{array}{l}\text { I dare take risky measures to hone my skills } \\
\text { (EC: -) }\end{array}$ & $\begin{array}{l}\text { I take risky action if it is } \\
\text { for the patient rescue }\end{array}$ \\
\hline & 9 & $\begin{array}{l}\text { I use my expertise as the main basis in } \\
\text { acting, thereby discussing the condition } \\
\text { of patients with my work partners, is an } \\
\text { inefficient activity } \\
\text { (EC: Discussion is needed to build } \\
\text { understanding) }\end{array}$ & $\begin{array}{l}\text { I use my expertise as } \\
\text { the main basis in acting, } \\
\text { discussing the condition } \\
\text { of the patient with my } \\
\text { colleagues/partners } \\
\text { partners when necessary }\end{array}$ \\
\hline & 18 & $\begin{array}{l}\text { I am willing to do any job although } \\
\text { sometimes it is beyond my capacity for the } \\
\text { realization of safe health care for patients } \\
\text { (EC : -) }\end{array}$ & $\begin{array}{l}\text { I make the best effort in } \\
\text { my work to achieve patient } \\
\text { safety }\end{array}$ \\
\hline $\begin{array}{l}\text { Integrated } \\
\text { Documentation } \\
\text { of patient care }\end{array}$ & 5 & $\begin{array}{l}\text { I feel no need to pay attention to the } \\
\text { documentation of care done by other health } \\
\text { professionals because it will not affect my } \\
\text { work. } \\
\text { (EC: -) }\end{array}$ & $\begin{array}{l}\text { I pay attention to the } \\
\text { documentation of care } \\
\text { made by other health } \\
\text { professionals when related } \\
\text { to my work }\end{array}$ \\
\hline
\end{tabular}




\begin{tabular}{|c|c|c|c|}
\hline & 15 & $\begin{array}{l}\text { I only document what I consider important } \\
\text { according to my professional judgment, } \\
\text { although all health professionals have a } \\
\text { responsibility to fill patient data correctly } \\
\text { and accurately. } \\
\text { (EC: -) }\end{array}$ & $\begin{array}{l}\text { I document what I consider } \\
\text { important according to my } \\
\text { professional judgment }\end{array}$ \\
\hline \multirow[t]{4}{*}{$\begin{array}{l}\text { Joint problem- } \\
\text { solving through } \\
\text { interprofessional } \\
\text { discussions }\end{array}$} & 5 & $\begin{array}{l}\text { I do not discuss the mistakes in decision } \\
\text { making or interventions in patients on } \\
\text { interdisciplinary discussions, because I } \\
\text { know the mistakes I have made and try to } \\
\text { prevent them next time. } \\
\text { (EC: mistakes need to be discussed as } \\
\text { a learning process for oneself and other } \\
\text { people) }\end{array}$ & $\begin{array}{l}\text { I discuss the mistakes } \\
\text { I make in either } \\
\text { decision making or } \\
\text { patient interventions } \\
\text { in interdisciplinary } \\
\text { discussions, so that the } \\
\text { same error will not recur }\end{array}$ \\
\hline & 9 & $\begin{array}{l}\text { I use my expertise as the main basis of } \\
\text { action, therefore discussing the patient's } \\
\text { condition for solving the problem } \\
\text { interdisciplinarily is inefficient } \\
\text { (EC: discussion is needed to build } \\
\text { understanding) }\end{array}$ & $\begin{array}{l}\text { I use my expertise as } \\
\text { the main basis of action, } \\
\text { and discuss the patient's } \\
\text { condition to solve the } \\
\text { problem interdisciplinarily } \\
\text { when necessary }\end{array}$ \\
\hline & 10 & $\begin{array}{l}\text { I refuse to explain the rationale for } \\
\text { the professional actions I take, in } \\
\text { interdisciplinary discussions on cases. } \\
\text { (EC: this principle of accountability should } \\
\text { be explained) }\end{array}$ & $\begin{array}{l}\text { I explain the rationale for } \\
\text { the professional actions I } \\
\text { take, in interdisciplinary } \\
\text { discussions on cases }\end{array}$ \\
\hline & 14 & $\begin{array}{l}\text { I just want to talk about the scope that I } \\
\text { handle according to my role and function, } \\
\text { because every profession has its own role } \\
\text { and autonomy } \\
\text { (EC: -) }\end{array}$ & $\begin{array}{l}\text { I speak of the scope that } \\
\text { I handle according to my } \\
\text { role and function, because } \\
\text { every profession has its } \\
\text { own role and autonomy }\end{array}$ \\
\hline
\end{tabular}

four components of the content model were relevant.

Furthermore, the expert judgment results on the content essence of the instrument/ content validity ratio (CVR) were illustrated in Table 3.

Table 3 showed the expert assessment for CVR on 4 components of the interprofessional

Table 3 Expert Assessment of Content Essence of Instrument/Content Validity Ratio (CVR)

\begin{tabular}{clcccl}
\hline No & $\begin{array}{c}\text { Model } \\
\text { Component }\end{array}$ & $\begin{array}{c}\text { Number of } \\
\text { Item }\end{array}$ & $\begin{array}{c}\text { Index Range } \\
\text { per Item }\end{array}$ & CVR & Explanation \\
\hline 1 & 18 & $-1 \mathrm{~s} . \mathrm{d}+1$ & 0.53 & $\begin{array}{l}\text { The number of items with a } \\
\text { ratio below 0 (negative): } 3 \\
\text { items, revision of language } \\
\text { structure and context }\end{array}$ \\
$\begin{array}{l}\text { Clinical } \\
\text { pathway } \\
\text { of patient } \\
\text { management }\end{array}$ & 18 & $-1 \mathrm{s.d}+1$ & 0.27 & $\begin{array}{l}\text { The number of items with index } \\
\text { below 0 (negative): } 7 \text { items, } \\
\text { revision of language structure } \\
\text { and context } \\
\text { Team } \\
\text { management } \\
\text { of patient }\end{array}$ \\
$\begin{array}{l}\text { Integrated } \\
\text { documentation } \\
\text { of patient Care }\end{array}$ & 16 & $-1 \mathrm{s.d}+1$ & 0.63 & $\begin{array}{l}\text { The number of items with index } \\
\text { below 0 (negative) : } 2 \text { items, } \\
\text { revision of language structure } \\
\text { and context }\end{array}$
\end{tabular}


F. Sri Susilaningsih : Development of Team Cohesiveness Measurement Instruments

4 Joint problem-

solving through

interprofessional discussions $\begin{array}{lll}14 & -1 \text { s.d }+1 & 0.28\end{array}$
The number of items with index below 0 (negative): 4 items, revision of language structure health service collaborative model, the highest ratio was on the component of integrated documentation of patient care, and the lowest was on the component of team management of patient. In each component, there was a CVR smaller than 0 (negative) and the context and structure of the language were revised according to the expert's input.
In general, a positive CVR $(>0)$ meant the content items were essential.

The results of the construct test in Table 5 above showed that the overall items on the four components of the interprofessional collaboration model were valid, the lowest validity score was on the team management of patient component $0.283>0.195$, and

\section{Table 4 Revision of Instrument Contents Based on Expert Assessment on CVR Test}

\begin{tabular}{lcll}
\hline Model Component & No of Item & \multicolumn{1}{c}{ Content of Statement/item } & \multicolumn{1}{c}{ Revision of item } \\
\hline $\begin{array}{l}\text { Clinical pathway of } \\
\text { patient management }\end{array}$ & 12 & $\begin{array}{l}\text { I do health counseling for patients and } \\
\text { their families, if necessary }\end{array}$ & $\begin{array}{l}\text { I conduct health } \\
\text { counseling for patients } \\
\text { and their families, so } \\
\text { they understand and be } \\
\text { involved in the necessary } \\
\text { care }\end{array}$ \\
& 13 & $\begin{array}{l}\text { I do not need to explain the actions I } \\
\text { take for patients to my colleagues in } \\
\text { the team }\end{array}$ & $\begin{array}{l}\text { I explain the actions I } \\
\text { take for patients to my } \\
\text { colleagues in the team } \\
\text { when necessary }\end{array}$ \\
& $\begin{array}{lll}\text { (Expert comment / EC: Necessary) } \\
14\end{array}$ & $\begin{array}{l}\text { I do medical / nursing interventions } \\
\text { independently, without consulting my } \\
\text { colleagues } \\
\text { (EC: depending on the level of } \\
\text { intervention) }\end{array}$ & $\begin{array}{l}\text { I perform clinical } \\
\text { interventions according to } \\
\text { my competence and level } \\
\text { of clinical authority }\end{array}$
\end{tabular}

Team management of patient
I make decisions quickly and act independently in performing my duty to serve the patient

4 I am willing to do the work that should be the responsibility of my colleague/partner if it is for the sake of the patient

5 I dare take risky measures to hone my skills

(EC: -)

9 I use my expertise as the main basis for acting, thereby discussing the condition of patients with my colleagues/partners, is an inefficient activity

(EC: Discussions are needed to build understanding)

10 I reject the task that is not within my authority
I make the right decision and act according to my clinical competence and authority in performing my duty to serve the patient

I am willing to do an overflow job (according to SPO) if it is for the benefit of the patient I take risky action if it is for the patient's rescue

I consider my skills as the main basis for acting, discussing the patient's condition with colleagues/partners when necessary

I reject the overwhelming task that is not within my authority 
F. Sri Susilaningsih : Development of Team Cohesiveness Measurement Instruments

\begin{tabular}{|c|c|c|c|}
\hline & 17 & $\begin{array}{l}\text { I feel satisfied if I can direct my } \\
\text { colleagues/partners to work hard to } \\
\text { realize the target group }\end{array}$ & $\begin{array}{l}\text { I feel satisfied if I can } \\
\text { direct my colleagues/ } \\
\text { partners work } \\
\text { according to the scope } \\
\text { of responsibility and } \\
\text { authority }\end{array}$ \\
\hline & 18 & $\begin{array}{l}\text { I am willing to do any job although it } \\
\text { is sometimes beyond my capacity to } \\
\text { do so for the realization of safe health } \\
\text { care for the patient } \\
\text { (EC : -) }\end{array}$ & $\begin{array}{l}\text { I make the best effort in } \\
\text { my work to achieve safe } \\
\text { patient health care. }\end{array}$ \\
\hline \multirow[t]{2}{*}{$\begin{array}{l}\text { Integrated documentation } \\
\text { Of patient care }\end{array}$} & 5 & $\begin{array}{l}\text { I feel no need to pay attention to the } \\
\text { documentation of care performed by } \\
\text { other health professionals because it } \\
\text { will not affect my work } \\
\text { (EC: Necessary) }\end{array}$ & $\begin{array}{l}\text { I pay attention to the } \\
\text { documentation of } \\
\text { care that other health } \\
\text { professionals make when } \\
\text { it comes to my work }\end{array}$ \\
\hline & 15 & $\begin{array}{l}\text { I only document what I consider } \\
\text { important according to my } \\
\text { professional judgment, even though } \\
\text { all healthcare professionals have } \\
\text { a responsibility to correctly and } \\
\text { accurately fill in patient data }\end{array}$ & $\begin{array}{l}\text { I document what I } \\
\text { consider important } \\
\text { according to my } \\
\text { professional judgment }\end{array}$ \\
\hline \multirow[t]{4}{*}{$\begin{array}{l}\text { Joint problem-solving } \\
\text { through interprofessional } \\
\text { discussions }\end{array}$} & 5 & $\begin{array}{l}\text { I do not discuss the mistakes in } \\
\text { making decisions or interventions } \\
\text { in patients in interdisciplinary } \\
\text { discussions, because it is important } \\
\text { that I know the mistakes I have made } \\
\text { and will try to prevent them next time } \\
\text { (EC: mistakes need to be discussed } \\
\text { as a learning process for oneself and } \\
\text { others) }\end{array}$ & $\begin{array}{l}\text { I discuss the mistakes } \\
\text { I made in either } \\
\text { decision-making or } \\
\text { interventions in patients } \\
\text { in interdisciplinary } \\
\text { discussions so that the } \\
\text { same error will not recur }\end{array}$ \\
\hline & 9 & $\begin{array}{l}\text { I use my expertise as the main } \\
\text { basis of action, therefore discussing } \\
\text { the patient's condition for solving } \\
\text { the problem interdisciplinarily is } \\
\text { inefficient } \\
\text { (EC: discussions are needed to build } \\
\text { understanding) }\end{array}$ & $\begin{array}{l}\text { I use my expertise } \\
\text { as the main basis of } \\
\text { action, and discuss } \\
\text { the patient's condition } \\
\text { to solve the problem } \\
\text { interdisciplinarily when } \\
\text { necessary }\end{array}$ \\
\hline & 10 & $\begin{array}{l}\text { I refuse to explain the rationale for } \\
\text { the professional actions I take, in } \\
\text { interdisciplinary case discussions } \\
\text { (EC: this principle accountability } \\
\text { should be explained) }\end{array}$ & $\begin{array}{l}\text { I explain the rationale for } \\
\text { the professional actions I } \\
\text { take, in interdisciplinary } \\
\text { case discussions }\end{array}$ \\
\hline & 14 & $\begin{array}{l}\text { I just want to talk about the scope that } \\
\text { I handle according to my role and } \\
\text { function, because every profession has } \\
\text { its own role and autonomy } \\
\text { (EC: -) }\end{array}$ & $\begin{array}{l}\text { I speak of the scope that } \\
\text { I handle according to my } \\
\text { role and function, because } \\
\text { every profession has its } \\
\text { own role and autonomy }\end{array}$ \\
\hline
\end{tabular}


F. Sri Susilaningsih : Development of Team Cohesiveness Measurement Instruments

Tabel 5 Test of Construct Validity and Reliability (N=237)

\begin{tabular}{clcccc}
\hline No & \multicolumn{1}{c}{$\begin{array}{c}\text { Model } \\
\text { Component }\end{array}$} & $\begin{array}{c}\text { Number of } \\
\text { item }\end{array}$ & $\begin{array}{c}\text { Validity } \\
\text { Score }\end{array}$ & $\begin{array}{c}\boldsymbol{\alpha} \\
\text { Cronbach }\end{array}$ & Explanation \\
\hline 1 & $\begin{array}{l}\text { Clinical pathway of patient } \\
\text { management }\end{array}$ & 18 & $0,283-0,613$ & 0.792 & $\begin{array}{c}\text { All items } \\
\text { are valid and } \\
\text { reliable }\end{array}$ \\
\cline { 3 - 5 } 2 & $\begin{array}{l}\text { Team management } \\
\text { of patient }\end{array}$ & 18 & $0,338-0,687$ & 0.872 & $\begin{array}{c}\text { All items } \\
\text { are valid and } \\
\text { reliable }\end{array}$ \\
\cline { 3 - 5 } 3 & $\begin{array}{l}\text { Integrated documentation } \\
\text { Of patient car }\end{array}$ & 16 & $0,479-0,662$ & 0.915 & $\begin{array}{c}\text { All items } \\
\text { are valid and } \\
\text { reliable }\end{array}$ \\
\cline { 3 - 5 } & $\begin{array}{l}\text { Joint problem-solving through } \\
\text { interprofessional discussions }\end{array}$ & 16 & $0,641-0,847$ & 0.963 & $\begin{array}{c}\text { All items } \\
\text { are valid and } \\
\text { reliable }\end{array}$ \\
\hline
\end{tabular}

Alpha Cronbach on the four components in the range of $0.792-0.963$ indicating that the instrument as a whole was reliable.

\section{Discussion}

The development of instrument grids and instrument items is an important key in the development of instrument items. The grids are grouped into 4 components of the interprofessional health care collaborative model adopted from the integrated inpatient care model (Susilaningsih, 2011). The development of instrument items in the four components of the model was based on the key elements of teamwork, which according to Sullivan (1999) are information sharing, sense of control, attention to overlapped responsibility and structuring intervention, and four core competencies of interprofessional collaboration (Schmitt, Blue, Aschenbrener, \& Viggiano, 2011) which are interprofessional values and ethics, interprofessional roles and responsibilities, interprofessional communication practices, teamwork and team-based practices. The number of items on the components of clinical pathways of patient management and team management of patient were 18, 9 items for collective culture tendencies and 9 items for individual culture tendencies respectively. The number of items on the components of patient care integrated documentation and joint problem-solving through interprofessional discussions were 16 , and 8 items were for collective culture trends and 8 items for individual culture trends respectively.

Content Validity Test. The content validity test was performed through expert assessment involving 5 experts from health professionals (minimum 4 experts) i.e. a health care management expert, medical practitioner, nursing practitioner, nursing academic, and a clinical pharmacist. Experts from the field of psychology and nutritionists provided expert insights through discussions with the researcher. The expert judgment was given to establish CVI in relation to the item relevance, and CVR is related to the essentiality of the item. CVI for the first 3 components of the clinical pathway of patient management, team management of patients and integrated documentation of patient care exceeded 0.8 , whereas in the joint problem solving component through CVI's interprofessional discussions was 0.77 approaching 0.8 , so in overall the entire instrument item contents was relevant (Polit \& Beck, 2006). This CVI assessment was required to revise, replace or remove irrelevant items. From the assessments and written comments given by the experts, there revised items were 3 items on the clinical pathway of patient management component, 3 items on the team management of patient component, 2 items on the integrated documentation of patient care, and 4 items on the joint problemsolving through interprofessional discussions component. No items were removed after the CVI assessment. The expert judgment was to establish CVR in relationship to the essentiality of the instrument item. The 


\section{F. Sri Susilaningsih : Development of Team Cohesiveness Measurement Instruments}

assessment experts for CVR were the same experts who assessed CVI. In general, the CVR on all four components was positive (0.27-0.63), meaning that in general, the instrument contents were essential. However, when viewed per item there were some items whose CVR was negative (below 0 ), and from those items the structure and context of the sentence were revised i.e 3 items in the clinical pathway component, 7 items in the team managementof patient component, 2 items in the integrated documentation component and 4 items in joint problemsolving through interprofessional discussions component.

The process of revising the instrument item both related to the relevance and essence of the instrument contents was conducted by taking into account the expert comments, the revision of the instrument contents was performed on the item whose CVI score was $<0.75$ and the CVR score was negative. In the clinical pathways of patient management, both from the relevance and essence of the instrument contents, 3 items were revised. On two of them i.e. items no 13 and 14, the content context were revised. One other item was no 11 , revisions were made regarding the relevance of the contents, and one item no 14 , a revision was performed related to the essence of the item. In item no 11, the contents of the item were considered to tend to indicate collective culture whereas the number was an item for an individual culture indicator.The revision of items was performed by changing the context towards culture.

On the team management of patient component, three items which were number 5, 9 and 18 required revisions on the relevance and essence of the contents of the instrument. One expert commentary for no 9 emphasized the need for discussion to improve understanding. On those three numbers revisions were performed in the sentence context. On four other numbers revisions were performed to the essence of the instrument contents, i.e. on numbers 2,4 , 10 and 17 as the CVR was negative.

On the integrated documentation of patient care component, two items needed to be revised from the relevance and essence of item contents, both items were statement items number 5 and 15 . The focus of revision was on the importance of attention to the content of the documentation from disciplinary partners as professional considerations for the continuity of care.

On the joint problem-solving through interprofessional discussions component, there were four items that needed revisions both of the relevance and essence of the item contents. The four items were number 5, 9, 10 and 14. The focus of discussion of number 5 was to place emphasis on the importance of addressing errors in services to prevent recurring events; the focus of revision of number 9 was the emphasis on the need for interprofessional discussions to build understanding among professional partners. The revision of item number 10 was on the importance of explaining the rationale of action in interdisciplinary discussions, while revisions to item number 14 put emphasis on the role and autonomy of each profession. No items were removed after the CVR test.

\section{The construct validity test}

All items on the four components of the model were statistically valid and the instrument reliability was indicated by $\alpha$ Cronbach in the range of $0.792-0.963$ with the total number of respondents 237 persons for two stages of validity test. The limitation of this construct test was that the ratio of respondents' background i.e. physicians, nurses, clinical pharmacists, and nutritionists, was not yet balanced but generally corresponded to the proportion and composition of health-care practitioners in hospitals. Overall, the respondents consisted of 44 physicians $(18.6 \%), 175$ nurses $(73.8 \%)$, 7 clinical pharmacy practitioners $(3 \%)$, and 11 nutritionists $(4.6 \%)$. One of the factors was the number of nurses was the largest compared to other health professionals in various health care management.

\section{Conclusion}

The process of developing a team cohesiveness measurement instrument in the practice of interprofessional health care collaboration has been completed and compiled a valid set of instruments (with $r$ in the range of $0.283-0.847>0.195$ ) and 
F. Sri Susilaningsih : Development of Team Cohesiveness Measurement Instruments

reliable with $\alpha$ Cronbach on four model components, namely the clinical pathway of patient management, team management of patient, integrated documentation of patient care and joint problem-solving through interprofessional discussions was in the range of $0.792-0.963$, thus this instrument can be used. As an original creation, this instrument has been recorded at the Ministry of Justice and Human Rights of the Repubic of Indonesia with number 000100340.

\section{References}

Cohen, M.B. (2005). Why culture matters in health care, paper presented at community voices summit: Health care in a multicultural society. Available at http:// www.communityvoices.org.

Huber, L. (2010). Interdisciplinary teamwork helps quality effort reach new height. $A O R N$ Journal, 92(3), 345.

Larsson, H., Tegern, M., Monnier, A., Skoglund, J., Helander, C., Persson, E., et al. (2015) Content validity index and intraand inter-rater reliability of a new muscle strength/endurance test battery for Swedish Soldiers. PLoS ONE, 10(7): e0132185. https://doi.org/10.1371/journal.pone.013218.

Lawshe, C.H. (1975). A quantitative approach to content validity. Personnel Psychology, 28, 563-575. doi:10.1111/j.1744-6570.1975. tb01393.x.
Petri, L. (2010). Concept analysis of interdisciplinary collaboration. Nursing Forum, 45(2), 73-83.

Polit, F.D., \& Beck, C.T. (2006). Nursing research: Principles and methods (7th ed).

Reeves, S., Lewin, S., Espin, S., \& Zwarenstein, M. (2010). Interprofessional teamwork for health and social care. Blackwell Publishing Ltd. ISBN: 978-1-40518191-4.

Schmitt, M, Blue, A., Aschenbrener, C \& Viggiano, T (2011). Core competencies for interprofessional collaborative practice reforming health care by transforming health professionals' education. Academic Medicine, 86(11), 1351. doi: 10.1097/ ACM.0b013e3182308e39.

Sullivan, E.J. (1999). Creating nursing's futures: Issues, opportunities and challenges. Mosby, Inc., St Louis.

Susilaningsih, F.S. (2011). Model Pelayanan Rawat Inap Terpadu (MPRIT) sebagai basis integrasi antar profesi dalam pelayanan kesehatan di RS Pendidikan Dr Hasan Sadikin. [Disertasi]. Universitas Gajah Mada, Yogyakarta.

World Health Organization [WHO]. (2009). Human factors in patient safety: Review of topics and tools. Retrieved from http:// who.int/patientsafety/research/methods measures/human_factors/en/. 